\title{
Do Contextual Factors and Gender Influence Students' Language Attitude in Learning English?
}

\author{
Noor Rachmawaty \\ Faculty of Teacher Training and \\ Education \\ Mulawarman University \\ Samarinda, Indonesia \\ noorrachmawaty@fkip.unmul.ac.id
}

\author{
Weningtyas Parama Iswari \\ Faculty of Teacher Training and \\ Education \\ Mulawarman University \\ Samarinda, Indonesia \\ weningtyas.iswari@gmail.com
}

\author{
Nia Astuti \\ Faculty of Teacher Training and \\ Education \\ Mulawarman University \\ Samarinda, Indonesia \\ niaastuti03@gmail.com
}

\begin{abstract}
Language attitude and orientation are considered as one of the most important components in the success of learning a target language. The learning context in which students learn foreign language is also considered as variable which contribute to promote teaching and learning process. In addition, individual variable such as gender has its role in students' foreign language learning process. Such argument inspired the researchers of this study to investigate the attitude and orientation of the non-English major students in Mulawarman University towards learning English, and to know if their attitudes are influenced by their gender and contextual factors. This study is quantitative in nature and two sets of questionnaire were used in collecting the data. The findings of this study may be helpful for EFL teachers and curriculum designers in terms of giving additional arguments on the imperative of teaching English course to non-English major students in university context in Indonesia. In addition, it is hoped that this study will broaden the interest of other researchers and teachers to find out how language attitudes and orientation of non-English major students and their correlated factors (i.e. gender, contextual factors may contribute to students' successfulness in learning English.
\end{abstract}

Keywords: language attitudes and orientation, contextual factors

\section{INTRODUCTION}

The English language was declared as the working language of the Association of Southeast Asian Nations as manifested in the Article 34 of the ASEAN Charter in February 2009 as it [1]. As a result, such linguistic icon is being introduced as a compulsory subject in the primary curriculum in all ASEAN countries now with the exception of Indonesia [2]. However, in Indonesian Universities, English becomes one of the compulsory courses for students to take beside their main major courses.

Several considerations have been put by the universities concerning the reasons why English becomes one of the compulsory courses. English competence is required for someone to enter a good school/university, to gain a better future opportunity, or to obtain a better position at work [3]. In fact, knowledge of English has become the mark of an educated person in Indonesia [4]. These situations indirectly encourage decision makers at universities to make English as a compulsory course. By doing so, it is hoped that the students could be motivated to learn English as complementary knowledge and skill to their major.

There have been several studies in the Indonesian education context, which investigated language attitudes and other variables. A previous study conducted among the first year English Department students found that they had a positive attitude towards target and local culture reading materials [5]. Another study found little difference in students' attitudes towards English between senior high school students from both science class and social class [6]. Sixty pre-service mathematics teachers were found to have a positive instrumental attitude towards English [7]. A study on 55 senior high school students found that they had a positive attitude towards English [8]. Similarly, a study among 101 Senior High School students revealed that the students had a positive attitude towards English [9].

In Indonesia, the terms of learning context of English as a foreign language may take place in three different types of education namely formal education, non-formal education, and informal education. Learning should take place both inside and outside the class in order to achieve success in language learning because classroom has limitations in opportunities for learning, particularly providing limited affordance [10].

It is considered necessary to capture the context of English language learning in those educational settings in order to find out how contextual factors, such as classroom, learning situation, and teaching method, influence learning achievements [11]. The school environment plays an important role in the learning process of students. To achieve quality education, learning environment is an important variable. Quality environment is defined by availability of facilities, infrastructure and resources. Learning facilities include classrooms, desks, tables, toilets, kitchen, library, playing field among others [12]. Facilities contained in schools are very necessary in the learning process. Incomplete facilities will make the learning process hampered and will also affect the role of the teacher in delivering material to students. In addition, the roles of the teacher in the learning process, among others, are the communicator, organizer, conductor, motivator, director and guide, originator of ideas, broad disseminator, facilitator, evaluator, and educator. In the teaching and learning process as a whole the process of the teacher's role cannot be ruled out. Because learning is an interaction between educators in this case the teacher with students that produces changes in behavior.

Teachers should not use monotonous learning methods such as lectures or note-taking. In the learning process the teacher must be able to use good methods or methods of teaching so that students can feel interested or not bored during the learning process. This greatly affects students in learning. 
Many sociolinguistics have shifted their views, from traditionally made female dichotomy as a static, learning to a complex system of social relations and bipolar opposite in relation to language use, with regards to gender [13]. Gender differences need to be given attention since "the difference between the girls and boys has been attributed to reading engagement among the students [14]. Japanese social elements, such as the status of English as feminised academic and professional choices and women's marginalised status in Japanese mainstream society, underlie many women's positive attitudes towards English learning [15]. Results from previous studies show that the area of education, especially English language teaching, is one of the potential areas to observe the relationship of gender and other variables.

Language attitude is considered as one of the most important components in the success of learning a target language. The learning context in which students learn foreign language is also considered as a variable which contributes to promote teaching and learning process. In addition, an individual variable such as gender has its role in students' foreign language learning process. Such an argument inspired the researchers of this study to investigate the attitudes of the non-English major students in Mulawarman University towards learning English, and to know if their attitudes are influenced by their gender and contextual factors.

Most of the previous studies revealed positive findings about Indonesian students' attitudes towards different aspects of English. The previous studies were conducted on small scales with a small number of participants, with [9] having the biggest participants $(n=101)$. In addition, none of these studies involved students from different universities. The researchers in this study are motivated to measure the instrumental orientation of Indonesian students towards English because many Indonesian university students seem to learn English to meet the instrumental needs rather than integrative ones. This assumption is strengthened by the fact that English is one of the compulsory subjects learned and tested in universities in Indonesia.

Referring to the fact that language attitude is considered as one of the most important components in the success of learning a target language and how contextual factors may affect students' success in learning foreign language, therefore it is necessary to propose a study to reveal the relationship between the above mentioned variables. Addressing the problems above, this study is attempted to answer the following research questions:

1.How is the language attitude of the non-English major students toward learning English?

2. How is the perception of the non-English major students toward contextual factors in learning English?

3. Is there a significant relationship between the participants' language attitudes of the non-English major students toward learning English and contextual factors?

4. Is there any difference between male and female of nonEnglish major students' language attitudes in learning English?

5.Is there any difference between male and female of nonEnglish major students' perception on contextual factors?

\section{METHODS}

This research was a quantitative in nature and particularly adopted a survey study. In this study, the population was non-English major pre-service teachers in the Faculty of Teacher Training and Education. Four main study programs in the faculty involved in this study were Education Studies, Mathematics and Science, Social Studies and Language and Arts.

For a survey study, the numbers of minimum sample are 100 respondents [16]. After the sample size was determined, participants were selected by cluster random sampling. In this study, fifth semester students of each study program were participated with the total number of 188 participants.

Two different sets of questionnaire were used to gather data in this study. The first was a 26 items describing positive and negative situations on language attitude towards learning English and Bahasa Indonesia were responded to a 5-point Likert-type scale. The questionnaire was adapted from [17]. The items in the questionnaire were divided into positive towards English, positive towards Indonesian, positive towards English and negative towards Indonesian, positive towards Indonesians and negative towards English and positive towards English and Indonesian. The second questionnaire was the contextual factors and it was developed by [18]. The questionnaire consisted of 17 numbers and 86 items. Number 1-7 about learning English outside school that included out-of-school activities, learning resources at home, private English course, and parental involvement that consist of 21 items. Number 8-17 about learning English inside school that included classroom activities, second language use activities/tasks, fun activities, personalized activities, interaction, learning resources/facilities at school, teacher's English proficiency, learning materials, classroom atmosphere, teacher personality, and teaching skills that consist of 65 items. For positively worded statement, there are number 1-17 that consist of 82 items, while for negatively worded statement, there are number 14,16 and 17 that consist of 4 items (e.g. 14h, 16e, 16h, and 17d). The questionnaire uses a 6-point Likert scale, ranging from 1 to 6 for agreement scale (from Strongly Disagree to Strongly Agree).

Two sets of questionnaires were distributed to each group of students according to their convenient times. Descriptive and inferential non-parametric statistics were applied in the data analysis process.

\section{RESUlTS AND DISCUSSION}

The main findings from the quantitative data are divided into data from students' language attitude and data from the contextual factors.

\section{A. Findings}

\section{1) Students' Language Attitude}

The students' language attitude was measured using mean scores based on each of the subcategories. 
TABLE I. STUDENTS’ LANGUAGE ATTITUDE

\begin{tabular}{|lccccc|}
\hline \multicolumn{1}{|c}{ Subcategory } & N & Min & Max & Mean & $\begin{array}{c}\text { Std. } \\
\text { dev }\end{array}$ \\
\hline Positive towards English & 188 & 1.67 & 5.00 & 3.262 & .495 \\
\hline Positive towards Indonesian & 188 & 2.33 & 5.00 & 3.842 & .549 \\
\hline $\begin{array}{l}\text { Positive towards English and } \\
\text { negative towards Indonesian }\end{array}$ & 188 & 1.40 & 4.80 & 3.186 & .515 \\
\hline $\begin{array}{l}\text { Positive towards Indonesian } \\
\text { and negative towards } \\
\text { English }\end{array}$ & 188 & 2.00 & 5.00 & 3.704 & .547 \\
\hline $\begin{array}{l}\text { Positive towards English and } \\
\text { Indonesia }\end{array}$ & 188 & 2.00 & 5.00 & 3.739 & .538 \\
\hline
\end{tabular}

TABLE II. LeVEl of CONTEXTUAL FACTORS PerCeIVEd By THE STUDENTS

\begin{tabular}{|cl|c|c|}
\hline \multicolumn{2}{|c|}{ Contextual Factors } & Frequency & $\begin{array}{c}\text { Percentage } \\
(\%)\end{array}$ \\
\hline Interval & Category & & 22.3 \\
\hline $5 \leq \mathrm{X}<6$ & Very Good & 42 & 56.4 \\
\hline $4 \leq \mathrm{X}<5$ & Good & 106 & 19.7 \\
\hline $3 \leq \mathrm{X}<4$ & Average & 37 & 1.1 \\
\hline $2 \leq \mathrm{X}<3$ & Poor & 2 & 0.5 \\
\hline $1 \leq \mathrm{X}<2$ & Very Poor & 1 & 100.00 \\
\hline Total & 188 & \\
\hline Maximum Score & $4, .9$ & \\
\hline Minimum Score & 1.6 & \\
\hline Average & 3.8 & \\
\hline Standard Deviation & 0.537 \\
\hline Variance & 0.289 \\
\hline
\end{tabular}

TABLE III. ONE-SAMPLE KOLMOGOROV-SMIRNOV TEST

\begin{tabular}{|lccc|}
\hline & & $\begin{array}{c}\text { Language } \\
\text { Attitude Mean }\end{array}$ & $\begin{array}{c}\text { Contextual } \\
\text { Factors Mean }\end{array}$ \\
\hline $\mathrm{N}$ & Mean & 188 & 188 \\
\hline $\begin{array}{l}\text { Normal } \\
\text { Parameters }\end{array}$ & 3.42 & 3.82 \\
\hline & $\begin{array}{c}\text { a,b } \\
\text { Std. } \\
\end{array}$ & .298 & .537 \\
\hline & Absiation & & .056 \\
\hline & Positive & .077 & .077 \\
\hline & Negative & -.076 & -.056 \\
\hline Test Statistic & & .077 & .056 \\
\hline Asymp.Sig.(2tailed) & & $.009^{\mathrm{c}}$ & $.200^{\mathrm{c}, \mathrm{d}}$ \\
\hline
\end{tabular}

TABLE IV. CORRELATION BETWEen LANGUAGE ATTITUDES AND CONTEXTUAL FACTORS

\begin{tabular}{|c|c|c|c|c|}
\hline & & & $\begin{array}{c}\text { Language } \\
\text { Attitude Mean }\end{array}$ & $\begin{array}{c}\text { Contextual } \\
\text { Mean }\end{array}$ \\
\hline \multirow[t]{6}{*}{$\begin{array}{l}\text { Spearman's } \\
\text { rho }\end{array}$} & $\begin{array}{l}\text { Attitude } \\
\text { Mean }\end{array}$ & $\begin{array}{l}\text { Correlation } \\
\text { Coefficient }\end{array}$ & 1.000 & $.238^{* *}$ \\
\hline & & Sig. (2-tailed) & & .001 \\
\hline & & $\mathrm{N}$ & 188 & 188 \\
\hline & $\begin{array}{l}\text { Contextual } \\
\text { Mean }\end{array}$ & $\begin{array}{l}\text { Correlation } \\
\text { Coefficient }\end{array}$ & $.238^{* *}$ & 1.000 \\
\hline & & Sig. (2-tailed) & .001 & \\
\hline & & $\mathrm{N}$ & 188 & 188 \\
\hline
\end{tabular}

*. Correlation is significant at the 0.01 level (2-tailed).

TABle V. Students' Langauge Attitude and Perception on CONTEXTUAL FACTORS BY GENDER

Test Statistics ${ }^{\mathrm{a}}$

\begin{tabular}{cr|r} 
& Attitude Mean & Contextual Mean \\
\hline Mann-Whitney U & 3093.500 & 3095.500 \\
\hline Wilcoxon W & 12273.500 & 4526.500 \\
\hline Z & -1.444 & -1.436 \\
\hline Asymp. Sig. (2-tailed) & .149 & .151 \\
\hline a. Grouping Variable: Gender & &
\end{tabular}

Table I reveals that students have positive attitude towards learning English and Indonesian. The participants appreciate learning Indonesian slightly more than learning English as shown in the mean score $(3.842>3.262)$. When the participants were asked about their attitude towards learning both Indonesian and English, they showed positive attitude with the mean value 3.739 (standard deviation of (0.538).

\section{2) Contextual Factors Percieved by the Students}

The second research question attempted to reveal the students' perception towards contextual factors, including students' English learning contexts inside and out of schools. The results of the questionnaire are presented in Table II.

As Table II demonstrates, the scores of the contextual factors as perceived by the students ranged from the highest 4.9 (Good) and the lowest 1.6 (Very Poor). The mean score of the whole sample was at medium level or Average category $(M=3.8)$ with $19.7 \%$ of the learners perceiving their language learning contexts belonging to this category. A greater percentage $(78.7 \%)$ of the students gave higher scores in the categories of Good and Very Good, while lower scores (Poor and Very Poor) were only given by $1.6 \%$ of the students.

\section{3) Relationship between the Students' Language Attitudes toward Learning English and Contextual Factors}

In attempt to find out the relationship between language attitudes and contextual factors, firstly a normality test was conducted to know whether the data was normally distributed or not. Table III presents the results from the statistical analysis for the normality test using one sample KS test.

As shown from table III the language attitude score of $\mathrm{N}(188)=.009, \mathrm{p}<.05$, and does significantly deviate from normality therefore the next computation will be using non parametric analysis.

Table IV shows that there was a significant positive correlation between language attitude and contextual factors $(r s[188]=.238, p<.001)$.

\section{4) Difference between Male and Female of Non-English Major Students' Language Attitudes in Learning English and Students' Perceptions on Contextual Factors}

This study also tried to reveal whether gender determined the students' language attitude in learning English and also their perception on contextual factors. Table V shows the result of statistical calculation comparing male and female students' language attitude and their perception on contextual factors.

Knowing that the language attitude and contextual factors' scores for male and female students were not normally distributed, a nonparametric (i.e., MannWhitney's $U$ ) independent samples $t$-test was used to compare scores of male and female students on language attitude in learning English and their perception on contextual factors. The Mann-Whitney $U$ test revealed a statistically not significant gender difference in the language attitude score, $U=3093.500, p>.001$ and in contextual factor score, $U=3095.500, p>.001$ 


\section{B. Discussion}

Attitude is defined as a mental state includes beliefs and feelings. It becomes one of important concepts to understand human behavior and [19]. Beliefs are among the essential points that have a relation with learning [20]. If students believe that they cannot learn the new language successfully, this may hinder the learning process [21]. Attitudes towards language are the feelings about one's language and the languages of others [22]. English is one of the required subjects offered in universities in Indonesia for the nonEnglish major students. Previous study [23] revealed that the participants in the study had a positive attitude of Indonesian identity with a positive reception of the importance of the English language. Similarly, this study found that the nonEnglish major students had positive attitude towards learning English and Indonesian. This implied that the students had a strong bound on being and learning Indonesian as Indonesians and in the same time they respect the existence of English as foreign language that should be learned and its role in globalized world.

Learning may take place at school and out of school (e.g. home, private courses), and the place where learning takes place might determine the learning processes and results, as some learning environments can be more conducive for cognitive, affective, moral, and social development than others [24]. In Indonesia English is considered as a foreign language, and like in many other EFL settings, it is considered under difficult circumstances (e.g. lack of exposure to the target language). Under such a condition, the results of the study from the Contextual Factor Questionnaire showed that the learners perceived their EFL learning contexts in Average category with the mean score ranging from very good and the lowest very poor.

This average condition indicates that the learning contexts, either at home (e.g. parental encouragement and learning facilities) or at school (e.g. classroom activities, rapport, and teachers' proficiency and personality) have not yet provided students with an ideal environment for the target language acquisition. More efforts at the sides of students themselves and their significant others (e.g. peers, parents and lecturers of English) are needed for optimum learning results.

This research also found evidence that there was a significant, but weak, correlation between the students' language attitude and perceived contextual factors. It could be assumed that other factors (such as motivation) had more influence on either students' language attitude or perception towards learning context. [21] argues that motivation and the will to learn second language are factors that were considered much more important than the social ones. In other words, motivated students will have better progress in learning new language compared to low-motivated students. Referring to the weak correlation between language attitude and learning context, it seems that only certain factor, such as teaching and learning environment (seen as part of learning context) affects students' attitude towards learning English. Teaching and learning environment is related to teachers' role in the classroom. If the student has respect feelings towards the language teacher, this will help student to learn a language effectively. On the contrary, if the student does not like or does not have respect feeling towards the language teacher, the student might not be able to go through or engage in the teaching and learning process while the teacher is teaching [25].

With regards to language attitude, gender difference was not a determinant factor. The result of this study is in line with a study which investigated the gender differences in the attitudes of 400 non-English major students in Turkey [26]. The findings proved that both males and females showed equally positive attitudes towards learning English as a foreign language. However, previous similar study which looked at the relationships among five components of languages attitudes in terms of gender and socio-economic status (SES) by involving 256 participants from four universities in Yogyakarta showed a different result. It was found that gender was positively related to English language attitude where female learners had higher positive language attitudes than males did toward English [27]. With regards to the different findings, it could be assumed that both male and female students in this study viewed learning English important as English is one of the required subject in the university that they should pass and English skill is needed as the requirements for their career in the future. Therefore, both male and female students had equal positive attitude towards learning English as foreign language.

Similarly, comparison by gender revealed that overall both male and female students had similar perception towards their EFL contextual factors. The contextual factors can be considered from perspective of the language, the learner and the learning process. In the contextual factors, the environment is referred to as learning context. Learning context is the environment when the learners are situated in learning foreign language that includes the relationship established between the learners and their environment at a particular time [28]. The contextual factors within out-ofschool and at school contexts constituted the learners' overall perceptions towards the contextual factors that might influenced their achievement of English.

In this study, it was found that both male and female students viewed contextual factors equally the same. The reasons for no gender differences in contextual factors found in this study might closely related to the view that no more discrimination to women at society nowadays as the result of educational awareness [29]. Although previous study conducted by [29] in Pakistani context, but it seems to be applicable as well in Indonesia where this current study took place. People now generally agree towards the importance of education for both men and women. Unlike in the past, men were educationally more superior over women. This condition might trigger women to move away from their passivity and show their equal proficiency in learning English. This attitude had led to a healthy competition between men and women. In addition, by having positive perception towards EFL learning contexts would facilitate students to have better achievement in learning English.

\section{CONCLUSION AND SUGGESTION}

In the light with the findings of statistical analysis, it was illustrated that the non- English major of Mulawarman University students hold positive attitudes towards Indonesian Language and learning English language. Considering the students' perception on contextual factors, it was found that the students perceive learning context in 
average level. This study also revealed that there was positive correlation between students' learning attitude and their perception on contextual factors. It was also proved that there was no significant statistical difference in the students' attitudes towards learning English language and their perception on contextual factors due to gender.

Based on the results of this study, further studies should be developed in other to reveals more findings on students' attitudes towards their own native language and learning foreign language which are associated with contextual factors and gender.

\section{ACKNOWLEDGMENT}

The authors would like to thank Teacher Training and Education Faculty of Mulawarman University for supporting this research.

\section{REFERENCES}

[1] A. Kirpatrick, "English in ASEAN: Implications for regional multilingualism," Journal of Multilingual Development, vol. 23(4), 2012, pp. 331-344.

[2] A. Hashim and G. Leitner, "English as a lingua franca in Malaysia," The Asian Journal of Applied Linguistics, vol. 1(1), 2014, pp. 16-27.

[3] F.L. Siregar, "The language attitudes of students of English literature and D3 English at Maranatha Christian University toward American English, British English and Englishes in Southeast Asia, and their various context of use in Indonesia," Philippine ESL Journal, vol. 4, 2010, pp. 66-92.

[4] W.A. Renandya,'Indonesia," nn H. W. Kam \& R. Y. L. Wong (Eds.). Language policies and language education, Singapore: Eastern University Press.

[5] R.S. Rodliyah, E.D.A Imperiani, and L.L. Amalia, "Indonesian tertiary students' attitudes towards the use of local culture vs target culture reading materials in English reading class," Bahasa \& Sastra, vol. 14,2014 , pp. 109-120.

[6] R. Novianti, “Comparing students' attitudes towards English language in an Indonesian State High School,” AJE, vol. 1, 2015, pp. 203-219.

[7] W. Setyaningrum, Pre-service mathematics teachers' attitudes towards learning English: A case study in Yogyakarta," AIP Conference Proceedings 1868, 2017.

[8] E. Setianengsih, U Salam, and Z. Arifin, "Attitude towards English language learning A survey on the rural students of SMAN 2 Paloh,' Jurnal Pendidikan dan Pembelajaran, vol. 6, 2017, pp. 1-10.

[9] L. Setyowati, and M. Qibtiyah, "The eight graders writing attitude toward EFL writing in Indonesian context," International Journal of Languages' Education and Teaching, vol. 5(3), 2017, pp. 422-433.

[10] J.C. Richard, "The changing face of language learning: learning beyond the classroom," RELC Journal, 2014, pp. 1-18.

[11] C. Griffiths, Lessons from Good Language Learners. Cambridge: CUP, 2008
[12] M.U. Chepkonga, "Influence of learning facilities on provision of quality education in Early Childhood Development Centres in Kenya," International Journal of Education and Research. vol. 5(6),2017.

[13] R. Ellis, R. The study of second language acquisition. Oxford: Oxford University Press, 1994.

[14] M. Puteh, Z.M. Zin, and I. Ismail, "Reading performance of Malaysian students across gender in PISA 2012," 3L: The Southeast Asian Journal of English Language Studies, vol. 22(2), 2016, pp. 10912 .

[15] Y. Kobayashi, "Gender and education. P. 181-197. vol. 14(2), 2010, pp. 181-197.

[16] U. Sekaran, Research methods for business (Metode penelitian untuk bisnis, 4th ed., Salemba Empat, 2006.

[17] P.Y. Kharismawan and C.L. Mbato, "A correlational study between language attitudes and english language orientation of Indonesian EFL Learners". in press.

[18] W.P. Iswari, "Individual and Contextual factors and their influence on the English achievement of Senior High School students in Samarinda. Unpublished Dissesrtation: State University of Makassar, 2018 .

[19] G. Latchanna, and A. Dagnew, "Attitude of teachers towards the use of active learning methods," E-journal of All India Association for Educational Research, vol. 21(1), 2009.

[20] I. Ajwzen, “Attitudes, personality, and behaviour. Chicago: Dorsey Press, 1988

[21] F. Lennartsson, "Students' motivation and attitudes towards learning a second language:British and Swedish students' points of view," 2008, http://urn.kb.se/resolve?urn=urn:nbn:se:vxu:diva-2571

[22] D. Crystal, A dictionary of linguistics and phonetics, 4th ed., UK, 1997.

[23] M.D. Kurniasari and C.L. Mbato, "Indonesian students' language attitudes towards Indonesian And English through education and working frame," Language and Language Teaching Journal, vol. 21, 2018 .

[24] M. Williams, and R. Burden, Psychology for language teachers, Cambridge University Press, 1997.

[25] A.R. Abu-Melhim, "Attitudes of Jordanian college students towards learning English as a foreign language. College Student Journal, vol. 43(2), 2009, pp. 682-694.

[26] Z. Durer and E. Sayar, "Speaking Classes: voice your thoughts!," Procedia-Social and Bhavioural Sciences, vol. 70, 2013, pp. 15741579 .

[27] D.S. Paradewari and C.L. Mbato, "Language attitudes of Indonesians as EFL learners, gender, and socio-economic status, Language and Language Teaching Journal, vol. 21(1), 2018.

[28] P. Longcope, "Differences between the EFL and the ESL language learning contexts," Language and Culture Studies, vol. 30(2), 2009, pp. 303-320.

[29] M. Akram, and M. Ghani, "Gender and language learning motivation," SAVAP International, vol. 4(2) 2013 